\title{
References
}

Asmund, G. 1974: Hydrogeochemical investigations on river water in West, South and East Greenland. Rapp. Gronlands geol. Unders. 65, 71-73.

Bütler, H. 1954: Die stratigraphische Gliederung der Mitteldevonischen Serien im Gebiete von Kap Franklin am Kejser Franz Josephs Fjord in Zentral-Ostgrönland. Meddr Grønland $116,7,126 \mathrm{pp}$.

Graeter, P. 1957: Die sauren Devonischen Eruptivgesteine des Kap Franklingebiets am Kejser Franz Josephs Fjord in Zentral-Ostgrönland. Meddr Grønland 155,3, 102 pp.

Nielsen, B. L. \& Larsen, H. C. 1974: Airborne geophysical survey in central East Greenland. Rapp. Grфnlands geol. Unders. 75, 73-76.

\section{Sedimentology and stratigraphy of the Middle Jurassic - Lower Cretaceous rocks of the Wollaston Forland - Kuhn $\varnothing$ area, central East Greenland}

\section{Finn Surlyk and Lars B. Clemmensen}

The present investigation was carried out in order to gain information concerning the stratigraphy and sedimentology of the Upper Jurassic and Lower Cretaceous sediments in central East Greenland (fig. 27). We were especially interested in the following topics:

(1) To delineate sedimentary facies and interpret their depositional environment.

(2) To erect a strict lithostratigraphical scheme for the sedimentary sequence.

(3) To date the tectonic activity controlling the sedimentation at the Jurassic-Cretaceous boundary.

\section{Structural and depositional framework}

The Bathonian - Middle Volgian sediments of the Wollaston Forland area were deposited on the peneplaned surface of large, slightly westward tilted, fault-blocks in supratidal and marine nearshore intertidal to outer shelf environments. The sediments consist of light sandstones grading upwards into interlaminated sand-mudstone and dark mudstones deposited under euxinic conditions.

This first depositional cycle included in the Jameson Land Group (Surlyk et al., 1973) came to an end in early Middle Volgian (late Jurassic) time when large-scale faulting, partly along old N-S trending fault systems, broke up the East Greenland shelf into several westward tilted fault blocks (Vischer, 1943). Along the fault-scarps forming 
Fig. 27. Map showing the investigated area between $74^{\circ}$ and $76^{\circ} \mathrm{N}$. .

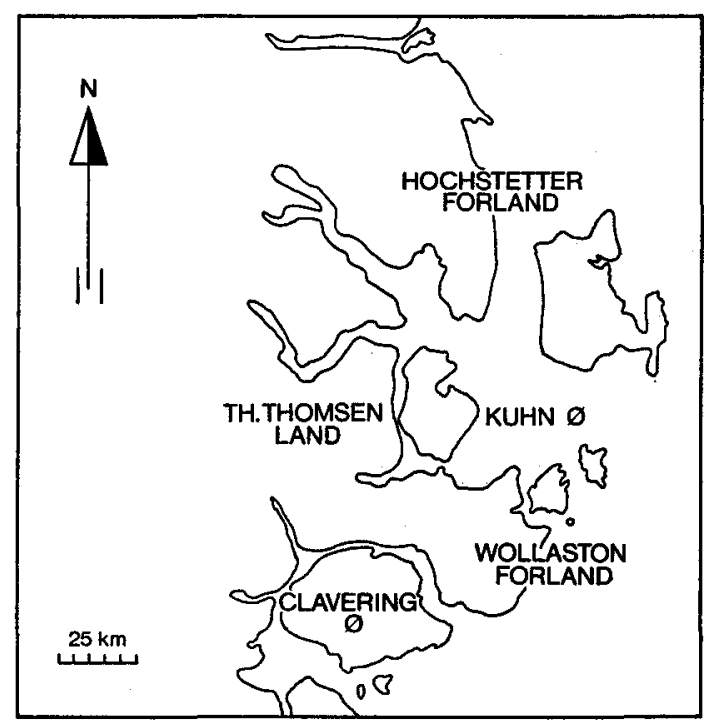

the westward border of each block, thick synorogenic clastic wedges were deposited. The sediments comprise breccias, conglomerates and sandstones which pass into sandstones and mudstones towards the east. This depositional regime, with repeated faulting activity, lasted into the early Cretaceous (Ryazanian). In the Valanginian renewed transgression formed an open marine shelf where calcareous mudstones and occasional turbidites were deposited.

The Valanginian is overlain unconformably by Aptian and Albian mudstones and the Hauterivian and Barremian were periods of emergence and non-deposition. Consequently, the Wollaston Forland Group which comprises the second, synorogenic sediment cycle ends with and includes Valanginian sediments.

\section{Lithostratigraphy}

We have been able to distinguish four Mesozoic formations in the discussed area ranging in time from Middle Jurassic (Bathonian) to Lower Cretaceous (Valanginian). These formations will be formally described elsewhere by the authors.

It must be stressed that the following is a preliminary report and that new or revised lithostratigraphical names are not formally designated here. A number of lithostratigraphical names employed by Surlyk et al. (1973) in the Jameson Land area, central East Greenland, are extended into the area currently under discussion.

\section{Jameson Land Group}

This group was defined by Surlyk et al. (1973) for the Middle Jurassic-Middle Volgian sediments in the Jameson Land area. 


\section{Vardeklфft Formation}

This formation (Surlyk et al., 1973) contains the oldest Jurassic rocks found in the described area and is subdivided into the Pelion Member (below) and the Jakobsstigen and Muslingebjerg Members.

Pelion Member ( $\approx$ Yellow Series of Maync, 1940)

This member consists of approximately $500 \mathrm{~m}$ of light yellow massive, horizontally laminated cross-bedded or ripple laminated, sandstone. Cross-bedding only locally displays a bipolar current pattern, otherwise being strictly unimodal towards the south.

Age-diagnostic fossils were not found although Bathonian ammonites were recorded by Maync (1947).

From the association of sedimentary structures it is suggested that the member was deposited in a subtidal-intertidal marine environment generally above wave-base, characterised by strong southward flowing tidal currents.

\section{Jakobsstigen Member $(\approx$ Grey Series of Maync, 1947)}

This member comprises sandy, grey, current and wave-laminated siltstones which attain a thickness of approximately $70 \mathrm{~m}$. Trace fossils are abundant.

In the basal part of the member a fauna of Cardioceras (Scarburgiceras) alphacordatum Spath (det. J. Callomon, 1975) indicates an early Oxfordian age (Mariae Zone, Praecordatum Subzone) while the top beds contain amoeboceratids of late Oxfordian age. Both boundaries are probably strongly diachronous, becoming younger towards the north.

It is suggested that the member represents sediments deposited under subtidal marine conditions characterised by weak intermittent wave and current activity.

\section{Muslingebjerg Member ( $\approx$ Muschelbjerg Formation of Donovan, 1957)}

The member is restricted to fine-grained, coal-bearing, light yellow sandstones on Hochstetter Forland. The sediment is mainly horizontally laminated and has yielded a few fossils probably of Upper Oxfordian or Lower Kimmeridgian age.

The sediments denote a lagoonal and shallow-marine environment (Clemmensen \& Surlyk, in press).

\section{Bernbjerg Formation}

This formation includes both the 'Black Series' (Maync, 1940) and the overlying 'Kuhn Beds' (Maync, 1947). The latter term was originally restricted to slightly younger and more sandy sediments. No significant lithological differences between the two series could be detected. Thus, we see no reason to support Maync's division and include all the sediments in the Bernbjerg Formation $(600 \mathrm{~m})$, together with the 'Shale Series' of Milne Land (Håkansson et al., 1971).

The formation is composed of dark, horizontally or rhythmic laminated, silt-rich mudstones. Locally the sediment may become more sandy. The sand occurs mainly 
as thin ripple-laminated horizons, but in a few cases rather thick sand beds with erosive bases have been seen. Yellowish or brownish, calcareous concretionary horizons are particularly characteristic of this formation, in which trace fossils are uncommon.

The formation contains ammonites (Amoeboceras etc.) indicating an Upper Oxfordian - Upper Kimmeridgian age.

The laminated non-bioturbated mudstones most probably delineate a low-energy euxinic shelf environment, whereas the sandy horizons indicate more agitated conditions. The thin ripple-laminated horizons could indicate storm activity while the thick sand beds might represent large-scale mass movement transporting shoreline sediments into the shelf environment.

\section{Wollaston Forland Group}

The group comprises the synorogenic Middle Volgian - Valanginian sediments of the Wollaston Forland area and is divided into 2 formations.

\section{Lindemans Bugt Formation}

This formation comprises the 'Rigi Series' and the Lower Niesen Beds of Maync (1947) and the 'Laugeites Beds' of Donovan (1957). The stratigraphy as defined by previous workers is unclear due to inconsistent stratigraphical nomenclature, a complicated facies pattern and limited biostratigraphical data.

The formation is divided into three members, Laugeites Ravine Member, Rigi Member and Niesen Member, of which the first is the stratigraphically lowest. The two younger members interfinger laterally. The formation consists of synorogenic breccias, conglomerates and sandstones passing laterally into fine-grained sandstones, siltstones and mudstones and rests with angular unconformity on the Bernbjerg Formation.

\section{Laugeites Ravine Member}

The member is in part equivalent to the 'Laugeites Beds' of Donovan (1957) which, however, were biostratigraphically defined. The member is only exposed in western Kuhn $\emptyset$ and northern Wollaston Forland and consists of silty mudstones with pebbly channel sandstones.

The sequence is fully marine and contains ammonites and bivalves indicative of a late Middle Volgian age.

The sedimentary environment is thought to be the marine part of a fan-delta at the foot of a fault scarp, laterally passing into prodelta mudstones.

\section{Rigi Member}

This member comprises about $400 \mathrm{~m}$ of synorogenic breccias, conglomerates and coarse sandstones accumulated along a major $\mathrm{N}-\mathrm{S}$ trending fault. The member is well exposed in northern and western Wollaston Forland and occurs as small outliers on Clavering $\varnothing$, Th. Thomsen Land and possibly western Kuhn $\varnothing$. 
The sequence is marine with abundant bivalves (Buchia), belemnites and more rarely ammonites suggesting a Middle Volgian - Middle (Upper?) Ryazanian age.

The breccias are interpreted as a submarine rock-fall avalanche formed at the foot of the fault scarp immediately after faulting. Rapid erosion after the strong uplift resulted in the formation of thick conglomerates and sandstones, probably transported by turbidity currents away from the narrow coastal fringe of fan-deltas developed shortly after faulting (Surlyk, in press). Pebble imbrication shows a very pronounced unimodal transport direction from west to east. The sandstones normally overlie the breccia-conglomerate complex.

\section{Niesen Member}

The Niesen Member consists mainly of dark mudstones and thinly interlaminated silty mudstones and fine sandstones (rhythmites). The sandstone layers display wave and current ripple-lamination. The member contains abundant bivalves and ammonites indicative of a middle Ryazanian age. The sediments were deposited in a mainly low-energy, offshore, marine environment.

\section{Palnatokes Bjerg Formation}

The formation comprises light grey mudstones (Albrechts Bugt Member), red mudstones (Rødryggen Member) and subordinate conglomerates and sandstones (Young Sund Member along the western basin margin and Falskebugt Member in eastern Wollaston Forland).

\section{Young Sund Member (= 'Young Sound Facies' of Maync, 1949)}

This member, exposed in western Wollaston Forland, consists of conglomerates, pebbly sandstones and sandstones. The overall character is like that of the Rigi Member but it is much thinner and less coarse. It differs from the Rigi Member mainly in containing intraformational clasts from the contemporaneous Albrecbts Bugt Member. The sandstones may show horizontal lamination and are well graded. They contain abundant marine fossils indicating a Middle Valanginian age. The sediments are interpreted as proximal turbidites.

\section{Falskebugt Member (= Falskebugt Beds of Maync, 1949)}

This member is only found along a N-S fault line in eastern Wollaston Forland where it wedges out rapidly in a westerly direction. The lithology and depositional environment is almost identical to that of the Young Sund Member.

\section{Albrechts Bugt Member ( $\approx$ Albrechts Bugt Facies of Maync, 1949)}

The member consists of light grey horizontally laminated mudstones which are often silty or sandy. Calcareous concretionary nodules often form continuous layers. Isolated thin sandstones occur and at one location on eastern Kuhn $\varnothing$ a turbidite sequence was found (Surlyk \& Clemmensen, in press). 
Fossils, notably Buchia, occur in abundance with belemnites and ammonites being less common. The age is considered to be Middle Valanginian although no faunas have previously been described from the Valanginian of this region (Maync, 1949).

The depositional environment is considered to have been an open marine shelf, generally below wave base.

\section{R $\phi$ dryggen Member (= Rødryggen Beds of Maync, 1949)}

This member overlies the Albrechts Bugt Member but is often removed by later, pre-Albian erosion. It consists of red almost structureless and often calcareous mudstones. Zoophycos burrows, belemnites and Buchia are common. Fragmented Inoceramus shells and rare brachiopods appear at some horizons. The age is believed to be Middle or Upper Valanginian (Maync, 1949). The depositional environment was an open marine shelf, but the nature and cause of the dark red colouration is not known.

$$
\text { Albian - Aptian }
$$

Dark horizontally laminated mudstones and thin sandstones overlie the westward tilted Bathonian - Lower Valanginian sediments with angular unconformity.

\section{References}

Clemmensen, L. B. \& Surlyk, F. in press: Upper Jurassic coal-bearing shoreline deposits, Hochstetter Forland, East Greenland. Sedimentary Geology.

Donovan, D. T. 1957: The Jurassic and Cretaceous Systems in East Greenland. Meddr Grønland 155,4, $214 \mathrm{pp}$.

Håkansson, E., Birkelund, T., Heinberg, C. \& Willumsen, P. 1971: Preliminary results of mapping the Upper Jurassic and Lower Cretaceous sediments of Milne Land. Rapp. Gronlands geol. Unders. 37, 32-41.

Maync, W. 1940: Stratigraphie des Küstengebietes von Ostgrönland zwischen $73^{\circ}-75^{\circ} \mathrm{N}$ Lat. Meddr Grønland 114,5, $34 \mathrm{pp}$.

Maync, W. 1947: Stratigraphie der Jurabildungen Ostgrönlands zwischen Hochstetterbugten $\left(75^{\circ} \mathrm{N}\right)$ und dem Kejser Franz Joseph Fjord $\left(73^{\circ} \mathrm{N}\right)$. Meddr Grønland 132,2, $223 \mathrm{pp}$.

Maync, W. 1949: The Cretaceous Beds between Kuhn Island and Cape Franklin (Gauss Peninsula), Northern East Greenland. Meddr Grønland 133,3, 291 pp.

Surlyk, F. in press: Fault controlled marine fan-delta sedimentation at the Jurassic-Cretaceous boundary, East Greenland. Submitted to IXth International Congress of Sedimentology. Nice, 1975.

Surlyk, F., Callomon, J. H., Bromley, R. G. \& Birkelund, T. 1973: Stratigraphy of the Jurassic - Lower Cretaceous sediments of Jameson Land and Scoresby Land, East Greenland. Bull. Grqnlands geol. Unders. 105 (also Meddr Grønland 193,5) 76 pp.

Surlyk, F. \& Clemmensen, L. B. in press: A Valanginian turbidite sequence and its palaeographical setting (Kuhn Ø, East Greenland). Bull. geol. Soc. Denmark.

Vischer, A. 1943: Die postdevonische Tektonik von Ostgrönlands zwischen $74^{\circ}$ und $75^{\circ} \mathrm{N}$ Br. Kuhn $\emptyset$, Wollaston Forland, Clavering $\emptyset$ und angrenzende Gebiete. Meddr Gr $\phi$ nland 133,1, 194 pp. 